\title{
Synthesis of New Azulene Derivatives and Study of Their Effect on Lipid Peroxidation and Lipoxygenase Activity
}

\author{
Eleni RekKa, ${ }^{*}$ Michael Chrysselis, Ioanna Siskou, and Angeliki Kourounakis \\ Department of Pharmaceutical Chemistry, School of Pharmacy, Aristotelian University of Thessaloniki; Thessaloniki \\ 54124, Greece. Received January 21, 2002; accepted April 10, 2002
}

\begin{abstract}
The relationship between free radicals and acute or chronic inflammation has been well established. We have previously reported the significant antioxidant activity of the natural azulene derivatives chamazulene and guaiazulene. Furthermore, some synthetic azulene analogues have been found to possess anti-inflammatory activity. In this investigation we report the synthesis of five 3-alkyl or 3-(hydroxy)alkylazulene-1-carboxylic acids and esters, from tropolone, via the corresponding furanone. The synthesised compounds were tested for their effect on the peroxidation of rat hepatic microsomal membrane lipids, applying the 2-thiobarbituric acid test. Their anti-inflammatory activity was evaluated in vitro by the offered inhibition of soybean lipoxygenase. All the tested molecules were found to inhibit lipid peroxidation by $100 \%$ at $1 \mathrm{~mm}$. They were also found to considerably inhibit lipoxygenase activity. The above results are discussed in relation to the structure and physicochemical properties of the examined azulene derivatives.
\end{abstract}

Key words antioxidant activity; lipoxygenase inhibition; azulene derivative; lipid peroxidation; inflammation

In aerobic life various molecular and cellular events involve oxygen activation and related radical reactions. A balance between the production and elimination of oxygen radicals is critical in human health and disease. When more active oxygen species are generated than can be counteracted by the defence system of the organism, the external application of synthetic or natural antioxidants appears to be a rational approach to the management of conditions associated with oxidative stress. ${ }^{1)}$

The radical-mediated oxidation of biomolecules, especially of lipids, can result into organ and tissue injury. The modification of biomolecules by lipid peroxidation products has a central role in most of the major health disorders in the industrialised world. ${ }^{2)}$ In particular, during the inflammation process, active oxygen species are generated at inflammatory sites and aggravate tissue damage. Thus, oxidative stress is considered to be one of the pathogenic factors in acute and chronic inflammation, while agents combining anti-inflammatory and antioxidant activities would be useful in the treatment of inflammation. Chamazulene and guaiazulene (Chart 1) have been found to possess anti-allergic, anti-inflammatory and anti-ulcer properties. ${ }^{3)}$ We have reported ${ }^{4,5)}$ that these natural, non toxic products are potent antioxidants. Furthermore, some synthetic azulenes have been reported to affect mediators of inflammation. ${ }^{6}$

In this investigation, we report the synthesis of five azulene derivatives, namely, 3-ethyl-, 3- $n$-butylazulene-1-carboxylic acids and their (2-hydroxy)ethyl esters, as well as 3(2-hydroxyethyl)azulene-1-carboxylic acid. In addition, we study their effect on lipid peroxidation and on lipoxygenase activity in vitro.

The rationale for the design of the above compounds is the preservation of the main azulene structure, in combination with a polar substituent at position 1 which would lower the high lipophilicity of the natural derivatives. Furthermore, we have taken into account that an essential structural element for the activity of azulenes affecting some inflammatory mediators is a carboxylic group or sulfonic acid moiety at position 1 of the azulene ring. ${ }^{6}$ Finally, we have found that the (2-hydroxy)ethyl group is a useful structural component con- tributing to the anti-inflammatory activity in a series of propiophenone derivatives. ${ }^{7)}$

Chemistry The synthesis of the azulene derivatives is shown in Chart 2. The structures of the intermediate and final products are confirmed spectroscopically (IR, ${ }^{1} \mathrm{H}-\mathrm{NMR}$ ) and by elemental analysis.

For the synthesis of the azulene derivatives, tropolone (1,<smiles>CC1=CC2=C(C)C=CC2=C(C)CC1</smiles>

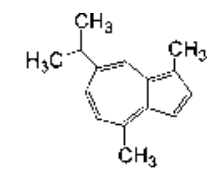

Chamazulene

Guaiazulene

Chart 1. Structures of Chamazulene and Guaiazulene

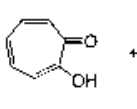

1

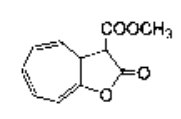

3
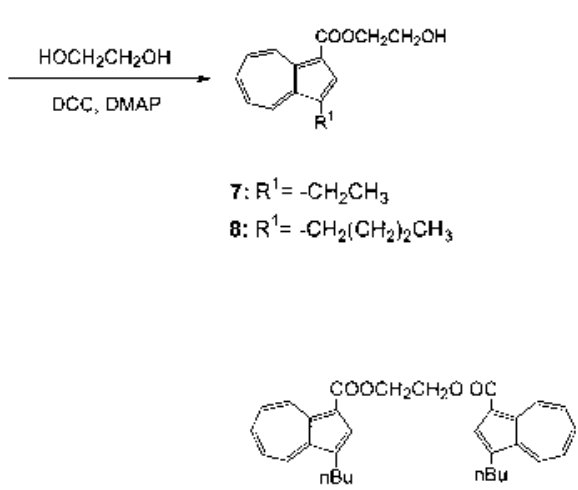

9
* To whom correspondence should be addressed. e-mail: rekka@pharm.auth.gr

Chart 2. Synthetic Route for the Preparation of the Azulene Derivatives 
Chart 2), via its tosyl ester (2), reacted with dimethyl malonate, an active methylene compound, in the presence of a strong base, to give the furanone 3 . The subsequent reaction of the furanone with the in situ generated morpholino enamines of aldehydes resulted in the formation of the 3-alkylazulene-1-carboxylic acids $\mathbf{4 b}-\mathbf{6 b}$, after the hydrolysis of their methyl esters $4 \mathbf{a}-6 \mathbf{6 a}$. The final products 7 and $\mathbf{8}$ were obtained after the reaction with the appropriate alcohol, using both 1,3-dicyclohexylcarbodiimide (DCC) and a catalytic amount of 4-dimethylaminopyridine (DMAP), at room temperature. Applying the above method for the preparation of the hydroxyethyl ester $\mathbf{8}$, a by-product was obtained in a substantial yield, which was identified to be the diester 9, having both hydroxylic groups of ethylene glycol esterified with the carboxylic acid $\mathbf{6 b}$.

The products were obtained in good yields. Spectral data and elemental analyses confirmed their structures.

\section{Results and Discussion}

The natural derivatives chamazulene and guaiazulene are potent antioxidants, nontoxic compounds, found to possess anti-inflammatory activity. However, a limitation to their broader therapeutic use is their high lipophilicity (clog $P$ about 6). We calculated the $\operatorname{cog} P$ values of the synthesised compounds, and found them to be noticeably lower, i.e. 4.09, $5.14,2.10$ for the acids $\mathbf{4 b}, \mathbf{5 b}, \mathbf{6 b}$, and $3.43,4.48$ for the esters 7 and 8.

The time course of lipid peroxidation, as affected by compounds $4 \mathbf{b}, 5 \mathbf{b}, \mathbf{6 b}, 7$ and 8 , at $0.5 \mathrm{~mm}$, is shown in Figs. 1A, B. All the tested compounds were found to completely inhibit the peroxidation reaction at $1 \mathrm{~mm}$, throughout the incubation period ( $2.5-45 \mathrm{~min}$ ), while their antioxidant activity was practically lost at $0.1 \mathrm{~mm}$ (data not shown). Compound $\mathbf{5 b}$, shown in Fig. 1A to be the most potent antioxidant at $0.5 \mathrm{~mm}$, was found to inhibit this reaction by $82 \%$ and $60 \%$ after 30 and $45 \mathrm{~min}$ of incubation, respectively, at $0.2 \mathrm{~mm}$ (data not shown).

We propose that the mechanism by which these derivatives exhibit their antioxidant activity is connected with the presence of an allylic-type of hydrogen on the substituent at position 3, which could be abstracted by the attacking radical. The resulting radical of the azulenic molecule could be stabilized by resonance, while it may be further affected by the inductive effect of the methyl or hydroxylic group of this substituent. Moreover, our results show that the antioxidant activity of the compounds increases with lipophilicity. It can be suggested that this increase in lipophilicity facilitates their access, retention, as well as interaction with biological membranes, the site of lipid peroxidation.

The effect of compounds $\mathbf{4 b}, \mathbf{5 b}, \mathbf{6 b}, \mathbf{7}$ and $\mathbf{8}$ on lipoxygenase activity at $100 \mu \mathrm{M}$ is shown in Figs. 2A, B. It was found that the most active was compound 6b (Fig. 2B), which demonstrated a $61 \%$ inhibition, followed by compound $\mathbf{5 b}$, which inhibited the enzyme by $40 \%$. For compounds $\mathbf{4 b}, \mathbf{7}$ and 8 approximately the same degree of inhibition (20$25 \%$ ) was observed.

It is known that the 5-lipoxygenase pathway is the source of a potent group of inflammatory mediators, the leukotrienes, implicated in neutrophil activation, which is associated with the induction of inflammation. Neutrophils may contribute to local tissue damage through the production
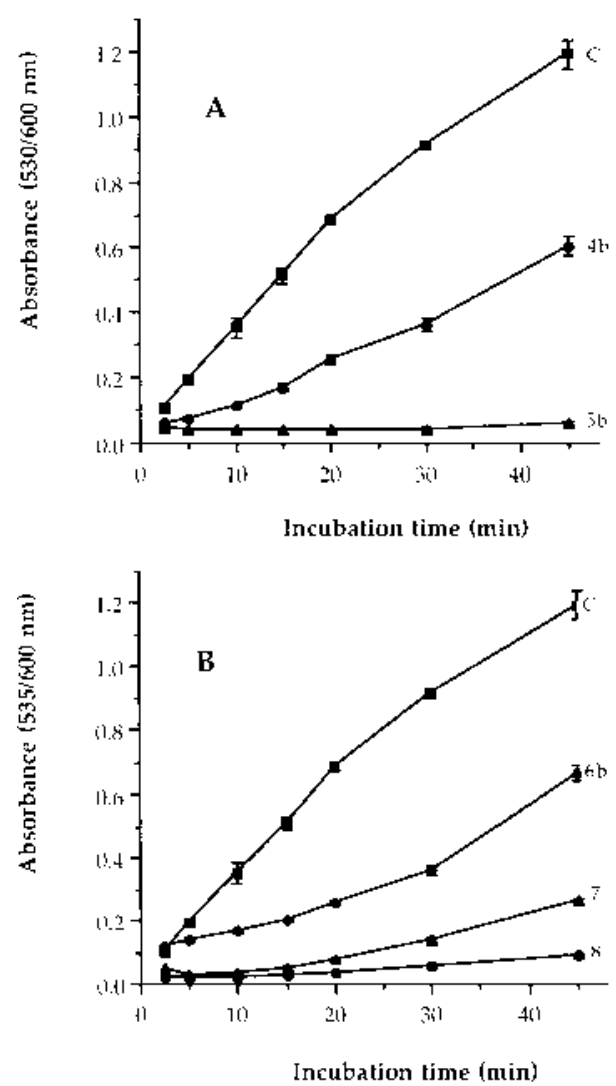

Fig. 1. Time Course of Lipid Peroxidation, as Affected by Compounds $\mathbf{4 b}$, 5b (Panel A), 6b, 7 and 8 (Panel B), at $0.5 \mathrm{~mm}$ (C: Control)
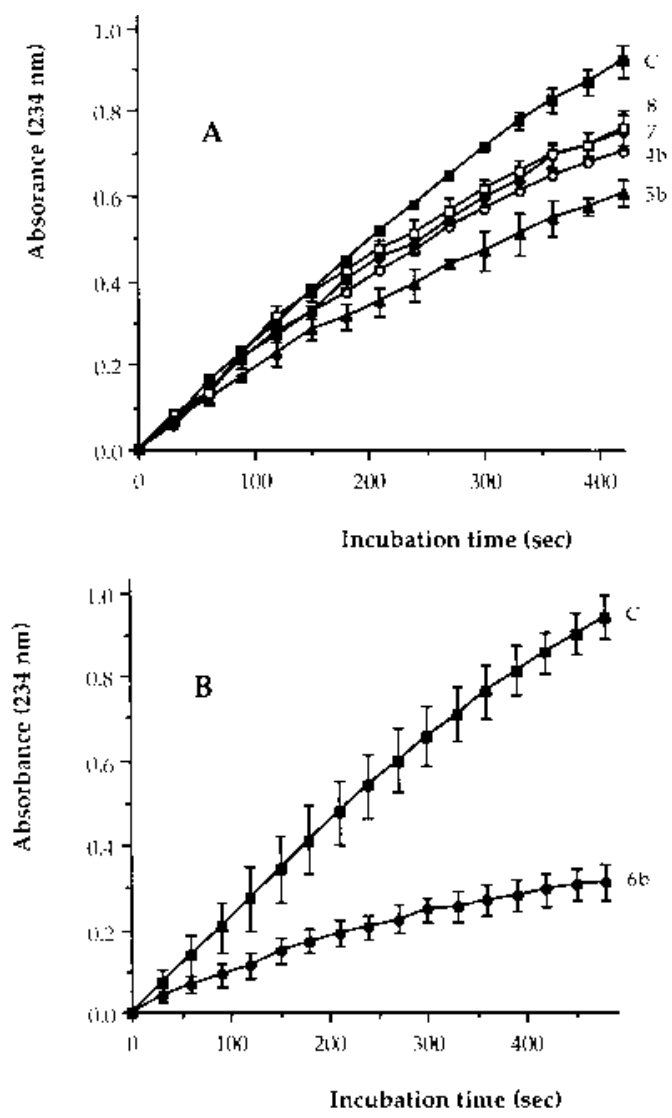

Fig. 2. Effect of $0.1 \mathrm{~mm}$ of Compounds $\mathbf{4 b}, \mathbf{5 b}, \mathbf{7}, \mathbf{8}$ (Panel A) and $\mathbf{6 b}$ (Panel B) on Lipoxygenase Activity (C: Control) 
of destructive proteinases and reactive oxygen or nitrogen metabolites. Several non-steroidal-anti-inflammatory drugs are lipoxygenase inhibitors, most of them having the ability to participate in redox processes. Since they inhibit lipid peroxidation, the synthesised compounds intervene in such reactions. Therefore, their effect on soybean lipoxygenase activity was examined, as an indication of potential anti-inflammatory activity. It is established that, even when the quantitative results of this assay cannot be extrapolated to the inhibition of mammalian lipoxygenase, the inhibition of plant lipoxygenase by known non-steroidal-anti-inflammatory drugs is at least qualitatively similar to their inhibition of the rat mast cell lipoxygenase and can be used as a simple screen for such activity. ${ }^{8}$ In our study, the offered inhibition of lipoxygenase did not seem to correlate completely with the antioxidant activity of the studied compounds, and the presence of a free carboxylic group appeared important for this enzyme inhibition. Compound $\mathbf{6 b}$ was a better lipoxygenase inhibitor than the other two carboxylic acids $\mathbf{4 b}$ and $\mathbf{5 b}$. This is considered to be due to the lower lipophilicity of $\mathbf{6 b}$, compared to $\mathbf{4 b}$ and $\mathbf{5 b}$. The above is in accordance with previous work reporting increased anti-inflammatory activity of azulene-sulphonic acids of comparable lipophilic character with compound $\mathbf{6} \mathbf{b}^{9)}$

In conclusion, this study indicates that new azulene derivatives with anti-inflammatory and antioxidant activities can be designed, and proposes structural and physicochemical features that contribute to this combination of actions. Further work is in progress, to extend the structural modifications, as well as the evaluation of activity in this series of compounds.

\section{Experimental}

Tropolone, dimethyl malonate, butanal, hexanal, 1,2-ethylenediol, 2,3-dihydrofuran, DMAP, DCC and $\mathrm{L}(+)$ ascorbic acid were purchased from Merck Chemical Company (Germany). 2-Thiobarbituric acid, soybean lipoxygenase (lipoxidase Type I-B) and sodium linoleate were from Sigma Chemical Company (U.S.A.). TLC was performed on silica gel $60 \mathrm{~F}_{254}$ aluminium sheets (Merck). For flash chromatography, silica gel 60 (40-63 mesh, Merck) was used. When petroleum ether is mentioned, it corresponds to the fraction with bp $40-60^{\circ} \mathrm{C}$. All other common chemicals and solvents of the appropriate purity were from various commercial sources.

Melting points were obtained on a MEL-TEMPII (Laboratory Devices, U.S.A.) apparatus and are uncorrected. IR spectra were recorded on a Perkin-Elmer 597 infrared spectrophotometer. ${ }^{1} \mathrm{H}-\mathrm{NMR}$ spectra were obtained with a Brucker AW $80 \mathrm{MHz}$ spectrometer. Chemical shifts $(\delta)$ are reported in ppm relative to tetramethylsilane (TMS), and signals are given as follows: s, singlet; d, doublet; t, triplet; q, quadruplet; m, multiplet. Elemental analyses were performed with a Perkin-Elmer $2400 \mathrm{CHN}$ analyzer.

Chemistry. 2-Tolylsulfonyloxytropone 2 Tropolone $(\mathbf{1}, 6.1 \mathrm{~g}, 50 \mathrm{mmol})$ was dissolved in freshly distilled pyridine $(15 \mathrm{ml})$ and to this a solution of 4toluenesulfonyl (tosyl) chloride $(10.5 \mathrm{~g}, 55 \mathrm{mmol})$ in dry chloroform $(15 \mathrm{ml})$ was added under stirring and cooling. The mixture was left at room temperature for $48 \mathrm{~h}$, while an additional amount $(1 \mathrm{~g})$ of tosyl chloride was added after $24 \mathrm{~h}$. Then, the precipitated solid was filtered off, the filtrate was washed with water, hydrochloric acid solution $(2 \mathrm{M})$, sodium hydrogen carbonate solution $(5 \%)$ and again with water. The organic layer was dried $\left(\mathrm{MgSO}_{4}\right)$, the solvent evaporated and the residue recrystallised from methanol. Yield $85 \%$, mp $151-154{ }^{\circ} \mathrm{C}$. ${ }^{1} \mathrm{H}-\mathrm{NMR}\left(\mathrm{CDCl}_{3}\right) \delta 2.4(\mathrm{~s}, 3 \mathrm{H}$, $\left.\mathrm{C}_{6} \mathrm{H}_{4} \mathrm{CH}_{3}\right), 7.5$ (m, 9H, $H_{\text {arom }}$ ). Anal. Calcd for $\mathrm{C}_{14} \mathrm{H}_{12} \mathrm{O}_{4} \mathrm{~S}: \mathrm{C}, 60.86 ; \mathrm{H}, 4.38$. Found: C, 61.02; H, 4.14 .

3-Methoxycarbonyl-2H-cyclohepta[b]furan-2-one $3^{10)}$ In anhydrous methanol $(30 \mathrm{ml})$, sodium $(300 \mathrm{mg})$ was added under stirring and cooling, followed by the successive addition of dimethyl malonate $(1.5 \mathrm{ml}, 13 \mathrm{mmol})$ in methanol $(30 \mathrm{ml})$, and 2-tolylsulfonyloxytropone $(1.8 \mathrm{~g}, 6.5 \mathrm{mmol})$ suspended in methanol $(100 \mathrm{ml})$. The mixture was stirred at room temperature for $12 \mathrm{~h}$. Then, methanol was evaporated, ethyl acetate was added and the mixture was washed with water, dried $\left(\mathrm{MgSO}_{4}\right)$, the solvent evaporated and the residue recrystallised from ethyl acetate-petroleum ether. Yield $75 \%$, mp $174-175^{\circ} \mathrm{C} .{ }^{1} \mathrm{H}-\mathrm{NMR}\left(\mathrm{CDCl}_{3}\right) \delta 3.9\left(\mathrm{~s}, 3 \mathrm{H}, \mathrm{COOCH}_{3}\right), 7.5\left(\mathrm{~m}, 5 \mathrm{H}, H_{\text {arom }}\right)$. Anal. Calcd for $\mathrm{C}_{11} \mathrm{H}_{8} \mathrm{O}_{4}$ : C, 64.71; H, 3.95. Found: C, 64.40; H, 3.73.

General Procedure for the Preparation of 3-Alkylazulene-1-carboxylic Acids $\mathbf{4 b}-\mathbf{6 b}$ To a solution of $\mathbf{3}(1 \mathrm{mmol})$ in absolute ethanol, the corresponding aldehyde $(3.5 \mathrm{mmol})$ and morpholine $(0.8 \mathrm{mmol})$ were added. The mixture was refluxed for $8-10 \mathrm{~h}$, then left at room temperature for $12 \mathrm{~h}$ under stirring, and finally ethanol was evaporated and the methyl esters $\mathbf{4 a}-$ 6a were isolated from the residue by flash chromatography and identified.

The esters were suspended in aqueous sodium hydroxide solution $(10 \%$ $\mathrm{w} / \mathrm{v})$, the mixture was refluxed for $12 \mathrm{~h}$, cooled, acidified with hydrochloric acid and extracted with ether. The organic layer was dried $\left(\mathrm{Na}_{2} \mathrm{SO}_{4}\right)$, ether was evaporated, the carboxylic acids $\mathbf{4} \mathbf{b}-\mathbf{6} \mathbf{b}$ were purified by flash chromatography and/or recrystallisation and identified.

3-Ethylazulene-1-carboxylic Acid 4b Prepared according to the general method, starting from the furanone $\mathbf{3}$ and butanal. The methyl ester $\mathbf{4 a}$ was isolated by flash chromatography using petroleum ether/ethyl acetate (50/1), as a dark blue oil. Yield 90\%. ${ }^{1} \mathrm{H}-\mathrm{NMR}\left(\mathrm{CDCl}_{3}\right) \delta: 1.4(\mathrm{t}, 3 \mathrm{H}, \mathrm{Ar}-$ $\left.\mathrm{CH}_{2} \mathrm{C}_{3}\right), 3.1$ (q, $\left.2 \mathrm{H}, \mathrm{Ar}-\mathrm{C}_{2} \mathrm{CH}_{3}\right), 3.9\left(\mathrm{~s}, 3 \mathrm{H}, \mathrm{Ar}-\mathrm{COOC} \underline{H}_{3}\right), 7.2-7.3(\mathrm{~m}$, $3 \mathrm{H}, \mathrm{C} 5-\underline{\mathrm{H}}, \mathrm{C} 6-\underline{\mathrm{H}}, \mathrm{C} 7-\underline{\mathrm{H}}), 8.1$ (s, $1 \mathrm{H}, \mathrm{C} 2-\underline{\mathrm{H}}), 8.3(\mathrm{~d}, 1 \mathrm{H}, \mathrm{C} 4-\underline{\mathrm{H}}), 9.5(\mathrm{~d}, 1 \mathrm{H}$, C8- - ). Anal. Calcd for $\mathrm{C}_{14} \mathrm{H}_{14} \mathrm{O}_{2}: \mathrm{C}, 78.48 ; \mathrm{H}, 6.59$. Found: C, 78.55; H, 6.67. The final product $4 \mathrm{~b}$ was obtained after recrystallisation from ether-petroleum ether. Yield $80 \%$, mp $186-187^{\circ} \mathrm{C} .{ }^{1} \mathrm{H}-\mathrm{NMR}$ as for $\mathbf{4 a}$, without the peak at $\delta$ 3.9. Anal. Calcd for $\mathrm{C}_{13} \mathrm{H}_{12} \mathrm{O}_{2}$ : C, 77.98; H, 6.04. Found: $\mathrm{C}, 77.63$; $\mathrm{H}, 5.94$.

3-n-Butylazulene-1-carboxylic Acid 5b According to the general procedure, starting from $\mathbf{3}$ and hexanal. The methyl ester $\mathbf{5 a}$ was isolated (dark blue oil, yield $85 \%)$ and identified as described for $4 a$. ${ }^{1} \mathrm{H}-\mathrm{NMR}\left(\mathrm{CDCl}_{3}\right) \delta$ : $1.2\left[\mathrm{t}, 3 \mathrm{H}, \mathrm{Ar}-\left(\mathrm{CH}_{2}\right)_{3} \mathrm{CH}_{3}\right] 1.6\left[\mathrm{~m}, 4 \mathrm{H}, \mathrm{Ar}-\mathrm{CH}_{2}\left(\mathrm{CH}_{2}\right)_{2} \mathrm{CH}_{3}\right], 3.0[\mathrm{t}, 2 \mathrm{H}, \mathrm{Ar}-$ $\mathrm{C}_{2}\left(\mathrm{CH}_{2}\right)_{2} \mathrm{CH}_{3}$ ], $3.9\left(\mathrm{~s}, 3 \mathrm{H}, \mathrm{Ar}-\mathrm{COOC} \underline{H}_{3}\right), 7.2-7.3(\mathrm{~m}, 3 \mathrm{H}, \mathrm{C} 5-\underline{\mathrm{H}}, \mathrm{C} 6-\underline{\mathrm{H}}$,

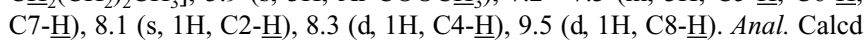
for $\mathrm{C}_{16} \mathrm{H}_{18} \mathrm{O}_{2}$ : C, 79.30; H, 7.49. Found: C, 79.08; H, 7.61. The final acid 5b was isolated by flash chromatography (petroleum ether/ethyl acetate 3/1) as an oil, yield 57\%. ${ }^{1} \mathrm{H}-\mathrm{NMR}$ as for $\mathbf{5 a}$, without the peak at $\delta: 3.9$. Anal. Calcd for $\mathrm{C}_{15} \mathrm{H}_{16} \mathrm{O}_{2}$ : C, 78.92; H, 7.06. Found: C, 78.56; H, 6.98.

3-(2-Hydroxyethyl)azulene-1-carboxylic Acid 6b According to the general procedure, starting from 3 and 4-hydroxybutanal. The methyl ester 6a was isolated (dark blue oil, yield $60 \%$ ) by flash chromatography (petroleum ether/ethyl acetate 20/1). ${ }^{1} \mathrm{H}-\mathrm{NMR}\left(\mathrm{CDCl}_{3}\right) \delta: 3.0(\mathrm{t}, 2 \mathrm{H}, \mathrm{Ar}-$ $\left.\mathrm{CH}_{2} \mathrm{CH}_{2} \mathrm{OH}\right), 3.6-3.9\left(\mathrm{~m}, 5 \mathrm{H}, \mathrm{Ar}-\mathrm{CH}_{2} \mathrm{CH}_{2} \mathrm{OH}, \mathrm{COOC}_{3}\right), 5.0[\mathrm{~s}, 1 \mathrm{H}, \mathrm{Ar}-$ $\left.\left(\mathrm{CH}_{2}\right)_{2} \mathrm{OH}\right], 7.2-7.3(\mathrm{~m}, 3 \mathrm{H}, \mathrm{C} 5-\underline{\mathrm{H}}, \mathrm{C} 6-\underline{\mathrm{H}}, \mathrm{C} 7-\underline{\mathrm{H}}), 8.1(\mathrm{~s}, 1 \mathrm{H}, \mathrm{C} 2-\underline{\mathrm{H}}), 8.3(\mathrm{~d}$, $1 \mathrm{H}, \mathrm{C} 4-\underline{\mathrm{H}}), 9.5(\mathrm{~d}, 1 \mathrm{H}, \mathrm{C} 8-\underline{\mathrm{H}})$. Anal. Calcd for $\mathrm{C}_{14} \mathrm{H}_{14} \mathrm{O}_{3}: \mathrm{C}, 73.04 ; \mathrm{H}, 6.09$. Found: C, 72.98; H, 6.11. The acid $\mathbf{6 b}$ was obtained in a yield of $20 \%$ by flash chromatography (petroleum ether/ethyl acetate 1/1) as a solid, mp 173- $1744^{\circ} \mathrm{C} .{ }^{1} \mathrm{H}-\mathrm{NMR}\left(\mathrm{CDCl}_{3}\right) \delta: 3.0\left(\mathrm{t}, 2 \mathrm{H}, \mathrm{Ar}^{-\mathrm{CH}_{2}} \mathrm{CH}_{2} \mathrm{OH}\right), 3.7(\mathrm{~m}, 2 \mathrm{H}$, $\left.\mathrm{Ar}-\mathrm{CH}_{2} \mathrm{C}_{2} \mathrm{OH}\right), 5.0$ [s, $\left.1 \mathrm{H}, \mathrm{Ar}-\left(\mathrm{CH}_{2}\right)_{2} \mathrm{O} \underline{\mathrm{H}}\right], 7.2-7.3(\mathrm{~m}, 3 \mathrm{H}, \mathrm{C} 5-\underline{\mathrm{H}}, \mathrm{C} 6-\underline{\mathrm{H}}$,

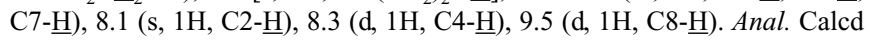
for $\mathrm{C}_{13} \mathrm{H}_{12} \mathrm{O}_{3}$ : C, 72.21; $\mathrm{H}, 5.59$. Found: $\mathrm{C}, 71.81 ; \mathrm{H}, 5.80$.

The starting 4-hydroxybutanal was obtained from 2,3-dihydrofuran, according to the literature. ${ }^{11)}$ Briefly, 2,3-dihydrofuran was added to an aqueous hydrochloric acid solution $(0.8 \mathrm{M})$ with stirring and cooling. The mixture was left at room temperature for $2 \mathrm{~h}$, then neutralised with sodium hydroxide $(1 \mathrm{M})$ and extracted with ether. After drying $\left(\mathrm{CaCl}_{2}\right)$ and evaporation of the solvent, 4-hydroxybutanal was obtained by distillation under reduced pressure $\left(\mathrm{bp}_{3} 46-48^{\circ} \mathrm{C}\right)$.

General Method for the Preparation of (2-Hydroxy)ethyl Esters 7 and 8 To a stirred solution of the appropriate carboxylic acid $\mathbf{5 b}$ or $\mathbf{6 b}$ $(1 \mathrm{mmol})$ in dry dichloromethane $(70 \mathrm{ml})$, DCC $(1.5 \mathrm{mmol}), 1,2$-ethylenediol $(8 \mathrm{mmol})$ and DMAP $(0.15 \mathrm{mmol})$ were successively added and the mixture was stirred at room temperature for $8 \mathrm{~h}$. Then, the formed precipitate was filtered off, the filtrate was washed with an aqueous $\mathrm{CH}_{3} \mathrm{COOH}$ solution $(5 \%$ $\mathrm{v} / \mathrm{v})$ and with water, dried $\left(\mathrm{MgSO}_{4}\right)$ and the final products were isolated by flash chromatography and identified.

(2-Hydroxy)ethyl 3-Ethylazulene-1-carboxylate 7 Prepared as described above, starting from $\mathbf{5 b}$. The final product (oil) was obtained in $67 \%$ yield by flash chromatography, using petroleum ether/ethyl acetate $(5 / 1) .{ }^{1} \mathrm{H}$ NMR $\left(\mathrm{CDCl}_{3}\right) \delta: 1.4\left(\mathrm{t}, 3 \mathrm{H}, \mathrm{Ar}-\mathrm{CH}_{2} \mathrm{CH}_{3}\right), 3.1\left(\mathrm{q}, 2 \mathrm{H}, \mathrm{Ar}-\mathrm{CH}_{2} \mathrm{CH}_{3}\right), 4.0(\mathrm{~m}$, $\left.4 \mathrm{H}, \mathrm{Ar}-\mathrm{COOC} \underline{H}_{2} \mathrm{CH}_{2} \mathrm{OH}\right), 4.5\left(\mathrm{t}, 1 \mathrm{H}, \mathrm{Ar}-\mathrm{COOCH}_{2} \mathrm{CH}_{2} \mathrm{OH}\right), 7.2-7.3(\mathrm{~m}$, $3 \mathrm{H}, \mathrm{C} 5-\underline{\mathrm{H}}, \mathrm{C} 6-\underline{\mathrm{H}}, \mathrm{C} 7-\underline{\mathrm{H}}), 8.1(\mathrm{~s}, 1 \mathrm{H}, \mathrm{C} 2-\underline{\mathrm{H}}), 8.3(\mathrm{~d}, 1 \mathrm{H}, \mathrm{C} 4-\underline{\mathrm{H}}), 9.5(\mathrm{~d}, 1 \mathrm{H}$, C86.78 .

(2-Hydroxy)ethyl 3-n-Butylazulene-1-carboxylate 8 Starting from $\mathbf{6 b}$, compound $\mathbf{8}$ (oil) was prepared, in a $50 \%$ yield, according to the general procedure, flash chromatographed with petroleum ether/ethyl acetate 
(50/1) and identified. ${ }^{1} \mathrm{H}-\mathrm{NMR}\left(\mathrm{CDCl}_{3}\right) \delta: 1.4$ [t, 3H, Ar- $\left.\left(\mathrm{CH}_{2}\right)_{3} \mathrm{C}_{3}\right], 1.6$ $\left[\mathrm{m}, 4 \mathrm{H}, \mathrm{Ar}-\mathrm{CH}_{2}\left(\mathrm{CH}_{2}\right)_{2} \mathrm{CH}_{3}\right], 3.0\left[\mathrm{t}, 2 \mathrm{H}, \mathrm{Ar}-\mathrm{CH}_{2}\left(\mathrm{CH}_{2}\right)_{2} \mathrm{CH}_{3}\right], 4.0(\mathrm{~m}, 4 \mathrm{H}$, $\left.\mathrm{Ar}-\mathrm{COOC} \underline{H}_{2} \mathrm{CH}_{2} \mathrm{OH}\right), 4.5\left(\mathrm{t}, 1 \mathrm{H}, \mathrm{Ar}-\mathrm{COOCH}_{2} \mathrm{CH}_{2} \mathrm{OH}\right), 7.2-7.3(\mathrm{~m}, 3 \mathrm{H}$, C5-H, C6-H, C7-H), 8.1 (s, 1H, C2-H), 8.3 (d, 1H, C4-H), 9.5 (d, 1H, C8H). Anal. Calcd for $\mathrm{C}_{17} \mathrm{H}_{20} \mathrm{O}_{3}$ : C, 74.97; H, 7.40. Found: C, 74.40; H, 7.50.

(3-n-Butylazulene-1-carboxy)ethyl 3-n-Butylazulene-1-carboxylate 9 During the preparation of the hydroxyethyl ester $\mathbf{8}$, a second product was formed (Chart 2), which was isolated as dark blue crystals by flash chromatography and identified to be the ester of $\mathbf{8}$ with the carboxylic acid 5b. Yield $35 \%, \mathrm{mp} 90-93{ }^{\circ} \mathrm{C} .{ }^{1} \mathrm{H}-\mathrm{NMR}\left(\mathrm{CDCl}_{3}\right) \delta$ : $1.1[\mathrm{t}, 6 \mathrm{H}$ $\left.2 \times \operatorname{Ar}-\left(\mathrm{CH}_{2}\right)_{3} \mathrm{CH}_{3}\right], 1.6\left[\mathrm{~m}, 8 \mathrm{H}, 2 \times \mathrm{Ar}^{-} \mathrm{CH}_{2}\left(\mathrm{CH}_{2}\right)_{2} \mathrm{CH}_{3}\right], 4.7$ (s, $4 \mathrm{H}, \mathrm{Ar}-$ $\left.\mathrm{COOCH}_{2} \mathrm{C}_{2} \mathrm{OCO}-\mathrm{Ar}\right), 7.2-7.3[\mathrm{~m}, 6 \mathrm{H}, 2 \times(\mathrm{C} 5-\underline{\mathrm{H}}, \mathrm{C} 6-\underline{\mathrm{H}}, \mathrm{C} 7-\underline{\mathrm{H}})], 8.1[\mathrm{~s}$, $4 \mathrm{H}, 2 \times(\mathrm{C} 2-\underline{\mathrm{H}})], 8.3[\mathrm{~d}, 2 \mathrm{H}, 2 \times(\mathrm{C} 4-\underline{\mathrm{H}})], 9.5$ [d, 2H, $2 \times(\mathrm{C} 8-\underline{\mathrm{H}})]$. Anal. Calcd for $\mathrm{C}_{32} \mathrm{H}_{34} \mathrm{O}_{4} \times 0.3 \mathrm{H}_{2} \mathrm{O}: \mathrm{C}, 78.78 ; \mathrm{H}, 7.09$. Found: $\mathrm{C}, 78.37 ; \mathrm{H}, 7.30$.

The lipophilicity of the synthesized compounds $\mathbf{4 b - 8}$, as well as of chamazulene and guaiazulene was calculated according to the method of Hansch and Leo ${ }^{12)}$ and expressed as $\operatorname{cog} P$ values.

Lipid Peroxidation Heat inactivated hepatic microsomal fraction from untreated male Fischer-344 rats $(180-220 \mathrm{~g})$ was prepared. ${ }^{13)}$ The incubation mixture contained the microsomal fraction, corresponding to $2.5 \mathrm{mg}$ of hepatic protein/ml (final concentration), or $4 \mathrm{~mm}$ fatty acid residues, ${ }^{14)}$ ascorbate $(0.2 \mathrm{~mm})$ in Tris- $\mathrm{HCl} / \mathrm{KCl}$ buffer $(50 \mathrm{~mm} / 150 \mathrm{~mm}, \mathrm{pH} 7.4)$ and the studied compounds, dissolved in dimethyl sulfoxide, at various concentrations $(0.1-1.0 \mathrm{~mm}$ ), or the solvent (control). The reaction of peroxidation was initiated by the addition of a freshly prepared $\mathrm{FeSO}_{4}$ solution $(10 \mu \mathrm{m})$ and the mixture was incubated at $37^{\circ} \mathrm{C}$ for $45 \mathrm{~min}$. Aliquots were taken at various time intervals, and lipid peroxidation was assessed by spectrophotometric (535 against $600 \mathrm{~nm}$ ) determination of the 2-thiobarbituric acid reactive material. ${ }^{4,13)}$ Under the same experimental conditions, DL- $(\alpha)$-tocopherol acetate, used as a reference, offered $100 \%$ and $10 \%$ inhibition of this reaction at $1 \mathrm{~mm}$ and $0.5 \mathrm{~mm}$ respectively. ${ }^{15)}$

Effect on Lipoxygenase Activity The reaction mixture contained (final concentrations) the test compounds, dissolved in $60 \%$ ethanol $(100 \mu \mathrm{M})$, or the solvent (control), soybean lipoxygenase, dissolved in $2 \%$ ethanol in $0.9 \% \mathrm{NaCl}$ solution $(250 \mathrm{u} / \mathrm{ml})$ and sodium linoleate $(100 \mu \mathrm{M})$, in Tris $/ \mathrm{HCl}$ buffer, $\mathrm{pH} 9.0$. The reaction was monitored for $7-8 \mathrm{~min}$ at $28^{\circ} \mathrm{C}$, by recording absorbance at $234 \mathrm{~nm}^{8}{ }^{8}$ The performance of the assay was checked using nordihydroguaiaretic acid $(10 \mu \mathrm{M})$ as a reference under exactly the same experimental conditions.

Acknowledgements E.R. and A.K. wish to acknowledge support for this work by the European Commission Financed Programme QLK6-CT1999-51170.

\section{References}

1) Paya M., Halliwell B., Hoult J. R. S., Free Rad. Res. Commun., 17, 293-298 (1992)

2) Rice-Evans C., Burdon R., Prog. Lipid Res., 32, 71-110 (1993).

3) Yanagisawa T., Kosakai K., Tomiyama T., Yasunami M., Takase K., Chem. Pharm. Bull., 38, 3355-3358 (1990).

4) Rekka E. A., Kourounakis A. P., Kourounakis P. N., Res. Commun. Molec. Pathol. Pharmacol., 92, 361-364 (1996).

5) Kourounakis A. P., Rekka E. A., Kourounakis P. N., J. Pharm. Pharmacol., 49, 938-942 (1997).

6) Yokota M., Uchibori S., Hayashi H., Koyama R., Kosakai K., Wakabayashi S., Tomiyama T., Bioorg. Med. Chem., 4, 575—591 (1996).

7) Gavalas A., Hadjipetrou L., Kourounakis P., J. Pharm. Pharmacol., 50, 583-591 (1998)

8) Taraporewala I. B., Kauffman J. M., J. Pharmaceut. Sci., 79, 173-178 (1990)

9) Yanagisawa T., Wakabayashi S., Tomiyama T., Yasunami M., Takase K., Chem. Pharm. Bull., 36, 641-647 (1988).

10) Nozoe T., Takase K., Kato M., Nogi T., Tetrahedron, 27, 6023-6035 (1971)

11) Bergman N.-A., Jansson M., Chiang Y., Kresge A. J., Yin Y., J. Org. Chem., 52, 4449—4453 (1987).

12) Hansch C., Leo A. (ed.), "Substituent Constants for Correlation Analysis in Chemistry and Biology," John Wiley \& Sons, New York, 1991.

13) Rekka E., Kolstee J., Timmerman H., Bast A., Eur. J. Med. Chem., 24, 43-54 (1989).

14) Eichenberger K., Bohni P., Winterhalter K. H., Kawato S., Richter C., FEBS Lett., 142, 59-62 (1982).

15) Andreadou I., Tasouli A., Bofilis E., Chrysselis M., Rekka E., TsantiliKakoulidou A., Iliodromitis E., Siatra T., Kremastinos D., Chem. Pharm. Bull., 50, 165-168 (2002). 